Tolerance is discussed. and a dose of 3 grains of prominal three times a day is shown to be satisfactory over long periods in adults.

I am indebted to Dr. Noel H. M. Burke, medical superintendent, Cell Barnes Colony, for permission to publish the results of this investigation. My thanks are also due to Professor Major Greenwood and his staff for kindly looking over the results.

REFERENCES

Blum, W. E. (1932). Dtsch. med. Wschr., 58, 696.

Heyde, W. (1932). Klin. Wschr., 11, 1874.

\section{PROMINAL IN THE TREATMENT OF EPILEPSY}

BY

\section{J. HENDERSON, M.B.}

Medical Superintendent, Royal Albert Institution, Lancaster

The results of the treatment of epilepsy by prominal in mental hospitals recorded in the British Medical Journal by Dr. L. G. Millar Page (March 14, 1936, p. 531) and Dr. Leonard Barber (March 28, 1936, p. 666) were so encouraging that it was decided to try the effect of prominal on the mentally defective patients in this institution who had had the greatest number of fits during 1935. The fourteen patients chosen were having various forms of treatment by drugs and diet, etc. Some had had luminal without any marked improvement, but were not receiving it at the time the use of prominal was begun. On April 1, 1936, every other kind of treatment was stopped, and in only one case has anything except prominal been given since then. One of the fourteen cases was discharged to another institution after six months, so that the figures below relate to thirteen only. All the thirteen patients had been having epileptic fits regularly for from three to twenty years, and the number of fits recorded in the preceding twelve months was rather more than in previous years.

The reduction in the number of fits in the first three weeks of treatment with prominal (twenty-eight against 124 in the corresponding period in 1935) was so remarkable that it was decided to keep exact records of these cases for the next twelve months. This has been most carefully done by Mr. D. D. Steadman, surgery attendant.

\begin{tabular}{|c|c|c|c|}
\hline \multirow[b]{2}{*}{$\begin{array}{l}\text { Case } \\
\text { No. }\end{array}$} & \multicolumn{2}{|c|}{ Number of Fits : April 1 to March 31} & \multirow{2}{*}{$\begin{array}{l}\text { Decrease in } \\
\text { Number of Fit }\end{array}$} \\
\hline & $\underset{1935-6}{\text { (Bromide, etc.) }}$ & $\begin{array}{c}\text { (Prominal) } \\
1936-7\end{array}$ & \\
\hline 1 & 581 & 107 & 474 \\
\hline 2 & 327 & 137 & 190 \\
\hline 3 & 191 & 55 & 136 \\
\hline 4 & 150 & 112 & 38 \\
\hline 5 & 122 & 2 & 120 \\
\hline 6 & 93 & 93 & - \\
\hline 7 & 69 & 67 & 2 \\
\hline 8 & 72 & 11 & 61 \\
\hline 9 & 62 & 7 & 55 \\
\hline 10 & 109 & 45 & 64 \\
\hline 11 & 51 & 13 & 38 \\
\hline 12 & 263 & 42 & 221 \\
\hline 13 & 38 & 5 & 33 \\
\hline Total & 2,128 & 696 & 1,432 \\
\hline
\end{tabular}

It will be seen that there was a reduction of just over two-thirds (67.3 per cent.) in the number of fits in twelve months.

To begin with, each patient was given 9 grains of prominal a day-that is, one tablet three times a daybut in nearly every instance this was found to be too much and had to be reduced-in some cases on April 2 and in the rest on April 4. The main symptom of overdosage was drowsiness, and the dose was reduced to 6 grains daily. In Cases 2, 4, 6, 7, and 10 the daily dose was further reduced to 3 grains, but after a few days was restored to 6 grains.

Case No. 1.-For several years this patient was quite useless and under constant observation owing to the frequency and severity of fits. Is now doing housework, and fits are less severe as well as less frequent.

Case No. 9.-Fits reduced from sixty-two to seven. Much brighter mentally.

Case No. 12.- Had been bedridden for six months owing to severity of fits. Is now up and back at school.

Case No. 8.-Has been at work regularly lately (shoemaker).

Cases 2, 3, and 4.-Not much improved mentally.

Cases 5 and 13.-Low-grade imbeciles, but much more lively and cheerful.

Case No. 10.-Physically improved. This patient has had an average of 118 fits a year for the last twenty years. (In 1900 he had craniectomy operation for epilepsy, without any improvement.)

Case No. 11.- Little change. This patient is 67 years old.

Case No. 6.-Has not benefited; 9 grains daily reduces the number of fits, but produces drowsiness to such an extent that he is unable to walk ; 6 grains daily has no more effect on the number of fits or their severity than bromides,

Case No. 7.-This is the only patient who has had any other treatment besides prominal. Up to the week ending November 14 he had had nearly 50 per cent. less fits than the previous year. During the week ending November 21 he had forty fits in three days, and was given bromide and chloral hydrate by mouth and by rectum in addition to prominal. Since then he has had only nine fits, against twenty-nine in the corresponding period of 1935 . He takes 3 grains of prominal daily.

During the time these patients have been undergoing this treatment there has been no alimentary disturbance. Nothing abnormal has been found in the urine, nor has the blood pressure been found to vary to any great extent. So far there has been no indication that the drug is losing its efficacy. The treatment is being continued, and other cases of epilepsy are receiving prominal. All those treated were suffering from grand mal only. Prominal has not been found to have any effect on the few cases of petit mal on which it has been tried.

J. J. C. P. A. Roovers (Nederl. Tijdschr. Geneesk., May 22, 1937, p. 2346) records the case of a girl, aged 5 years, who suffered from generalized calcinosis. The Wassermann, Müller, and Kahn reactions in the blood were negative. She was given 3 grammes of sodium citrate a day by mouth and calcium intravenously. In three weeks after the treatment was begun the calcium content of the blood rose from $11.5 \mathrm{mg}$. to $20 \mathrm{mg}$. per $100 \mathrm{c} . \mathrm{cm}$. of blood, and the phosphorus content from $4.7 \mathrm{mg}$. to $10.8 \mathrm{mg}$. per $100 \mathrm{c.cm}$. Slow but steady improvement followed. The calcium nodules subsided, the contractures disappeared, as did also the limitation of movements in the joints, and practically complete recovery took place. 